\title{
Changes in chemical composition of cover crops residue during decomposition
}

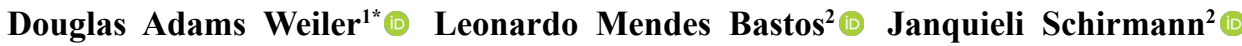 \\ Celso Aita $^{2}$ (D) Sandro José Giacomini ${ }^{2}$ (D)
}

${ }^{1}$ Coordenadoria Especial de Ciências Biológicas e Agronômicas, Universidade Federal de Santa Catarina (UFSC), 89520-000, Curitibanos, SC, Brasil. E-mail: douglas.weiler@ufsc.br. "Corresponding author.

${ }^{2}$ Centro de Ciências Rurais, Departamento de Solos, Universidade Federal de Santa Maria (UFSM), Santa Maria, RS, Brasil.

ABSTRACT: Crop residues decomposition are controlled by chemical tissue components. This study evaluated changes on plant tissue components, separated by the Van Soest partitioning method, during cover crop decomposition. The Van Soest soluble fraction was the first to be released from the crop residues, followed by cellulose and hemicellulose. Lignin was the crop residue component that suffered the least degradation, and for certain crop residue types, lignin degradation was not detected. The degradation of the main components of crop residues (soluble fraction, cellulose, hemicellulose and lignin) is determined by the chemical and structural composition of each fraction.

Key words: Van Soest soluble fraction, cellulose, hemicellulose, lignin.

Mudanças na composição química dos resíduos culturais de plantas de cobertura durante a decomposição

RESUMO: A decomposição de resíduos culturais é controlada pela composição química do tecido vegetal. O objetivo deste estudo foi avaliar as alterações que ocorrem nos componentes do tecido vegetal, separados pelo fracionamento de Van Soest, durante a decomposição de plantas de cobertura. A fração solúvel foi a primeira a ser liberada dos resíduos culturais, seguida pela celulose e hemicelulose. A lignina foi o componente dos resíduos culturais de menor degradação, sendo que em alguns resíduos culturais não foi possível detectar a degradação deste componente. A degradação dos principais componentes dos resíduos culturais (fração solúvel, celulose, hemicelulose e lignina) é determinada pela composição química e estrutural de cada uma destas frações.

Palavras chave: fração solúvel, celulose, hemicelulose, lignina.

Crop residues are the main source of carbon (C) for soil organic matter formation. The majority of the $\mathrm{C}$ present in crop residues is added to the soil in the form of three polymers: cellulose, hemicellulose and lignin, that are strongly intermeshed and chemically bonded by non-covalent forces and by covalent crosslinkages (PEREZ et al., 2002). The proportion of these polymers, along with $\mathrm{N}$ and polyphenol levels in plant tissue, determines the "residue quality". However, the quality of the residue cannot be considered constant as it varies during the decomposition process due to the different degradation rates of each of the crop residue components (SOUZA JR et al., 2017). Little is known about how changes in crop residues decomposition occur over time and how soil microorganisms regulate this important global C cycle step. Furthermore, this type of information is essential for parameterizing the decomposition process in models simulating $\mathrm{C}$ dynamics in the soil.

Studies that evaluated the degradation of different crop residue components, especially under field conditions, are scarce. This study evaluated the degradation dynamics of the soluble fraction, cellulose, hemicellulose and lignin of different summer cover crops residue undergoing decomposition at the soil surface.

The study was conducted under a no-till system on the experimental area of the Departamento de Solos from Universidade Federal de Santa Maria, RS. The soil is classified as Argissolo Vermelho Distrófico arênico (SANTOS et al., 2006), Typic Hapludalf according to Soil Taxonomy (SOIL SURVEY STAFF, 2014), and the climate of the region, according to Köppen, is classified as subtropical humid type Cfa2 (PEEL et al., 2007). 
The degradation of the crop residues was evaluated on the following species: velvet bean (Stilozobium niveum), pearl millet (Pennisetum americanum), pigeon pea (Cajanus cajan), sunn hemp (Crotalaria juncea), crotalaria (Crotalaria spectabilis) and jack bean (Canavalia ensiformis). These species were cultivated without mineral fertilizer addition.

Aboveground crop residues were collected at flowering and air-dried before experimental unit assembly. A subsample of the material was ovendried at $65^{\circ} \mathrm{C}$ for dry matter determination. The cover crop components degradation was evaluated by the use of decomposition bags with the dimensions of 0.2 x $0.2 \mathrm{~m}$, with mesh size $0.5 \mathrm{~mm}$. The quantity of crop residue added to each bag was proportional to the dry matter production of each species $\left(\mathrm{Mg} \mathrm{ha}^{-1}\right)$, being as follow: velvet bean (5.4); pearl millet (11.1); pigeon pea (5.3); sunn hemp (12.1); crotalaria (4.7) and jack bean (5.8).

The bags were placed on the soil surface and design was randomized complete block with four replicates. The bags were sampled at $0,14,35$, 70 and 140 days after bags placement on the field. After each sampling event, crop residues were ovendried $\left(65^{\circ} \mathrm{C}\right)$ until constant weight was achieved for the determination of remaining dry matter content. After being dried and ground, chemical composition of crop residue from each sampling date was determined by VAN SOEST (1963) partitioning method, as described by REDIN et al. (2014). Briefly, the digestions were performed by boiling residues with neutral and acid detergent solutions in digester block at $150{ }^{\circ} \mathrm{C}$ for 1 hour. After digestion, the samples were filtered by vacuum suction and washed with hot water and acetone. The fibers were dried at $105{ }^{\circ} \mathrm{C}$. The Van Soest soluble fraction (SF) was determined by the sample weight difference before and after neutral digestion. The hemicellulose (HEM) content was determined by the difference between neutral fiber and acid detergent fiber. The cellulose (CEL) content of the fiber acid was determined after residues digestion in $\mathrm{H}_{2} \mathrm{SO}_{4}$. The lignin (LIG) content was determined after burning the remaining material in a muffle furnace at $500{ }^{\circ} \mathrm{C}$. $\mathrm{C}$ and $\mathrm{N}$ contents were determined by dry combustion using an elemental analyzer model Flash EA 1112 (Thermo Fisher Scientific, Bremen, Germany). A subsample (1 g) was incinerated in a muffle furnace at $550{ }^{\circ} \mathrm{C}$ for three hours for ash determination, in order to express the results free of soil contamination.

The plant tissue component with the highest release rate during the initial period of decomposition was SF (Figure 1A). The rapid degradation of this fraction is due to the fact that it is composed of sugars, free amino acids and organic acids, all easily degradable by the microbial population. According to COTRUFO et al. (2015), the labile compounds of crop residues can be easily stabilized in the soil because microorganisms used this source of $\mathrm{C}$ more efficiently. Moreover, part of these components can be leached out of the plant tissue due to rainfall water movement without the need of microorganism decomposition (BERG \& MCCLAUGHERTY, 2020). Crop residue SF release of all species was higher during the first 35 days and gradually decreased, except for jack bean, which SF decreased at higher rates than other species, even at the later stages of the experiment. Jack bean, which had the highest initial tissue concentration of SF (Table 1), was the species with the least proportion of this fraction on the crop residues $(7 \%)$ at the end of the experiment, at 140 days (Figure 1A). The inverse relation between initial and remaining SF on crop residues after 140 days $\left(\mathrm{r}^{2}\right.$ $=0.82$ ) suggested that crop species containing higher proportion of labile fraction can promote accelerated and increased microbial growth, resulting in the fast degradation rate of this fraction.

The degradation of cellulose from the crop residues differed among species throughout the evaluation period, being the highest and lowest remaining cellulose percentages at 140 days observed on pearl millet (54\%) and jack bean (23\%) crop residues, respectively. According to VAULAWE et al. (1994), SF can cause a priming effect on the decomposition of the most recalcitrant fraction of the crop residues due to its high lability and $\mathrm{N}$ availability. Nonetheless, this effect was not directly proportional to the initial levels of SF on the plant tissues used in our study. BERTRAND et al. (2009) did not find an effect from the soluble fraction on the decomposition of the most recalcitrant fraction on wheat internode tissue. This suggested that other factors may interfere on cellulose degradation, such as the cellulose proportion with crystalline and amorphous structure (PEREZ et al., 2002) and the lignin content (BERG \& MCCLAUGHERTY, 2020).

The hemicellulose degradation was contrasting among the crops, splitting them in two groups (Figure 1C). On the first group, comprised of velvet bean and crotalaria, hemicellulose decomposition was low during the first 70 days, whereas on the second group, comprised of pearl millet, pigeon pea, sun hemp and jack bean, hemicellulose was decomposed at faster rates. The increment in absolute quantities of hemicellulose 

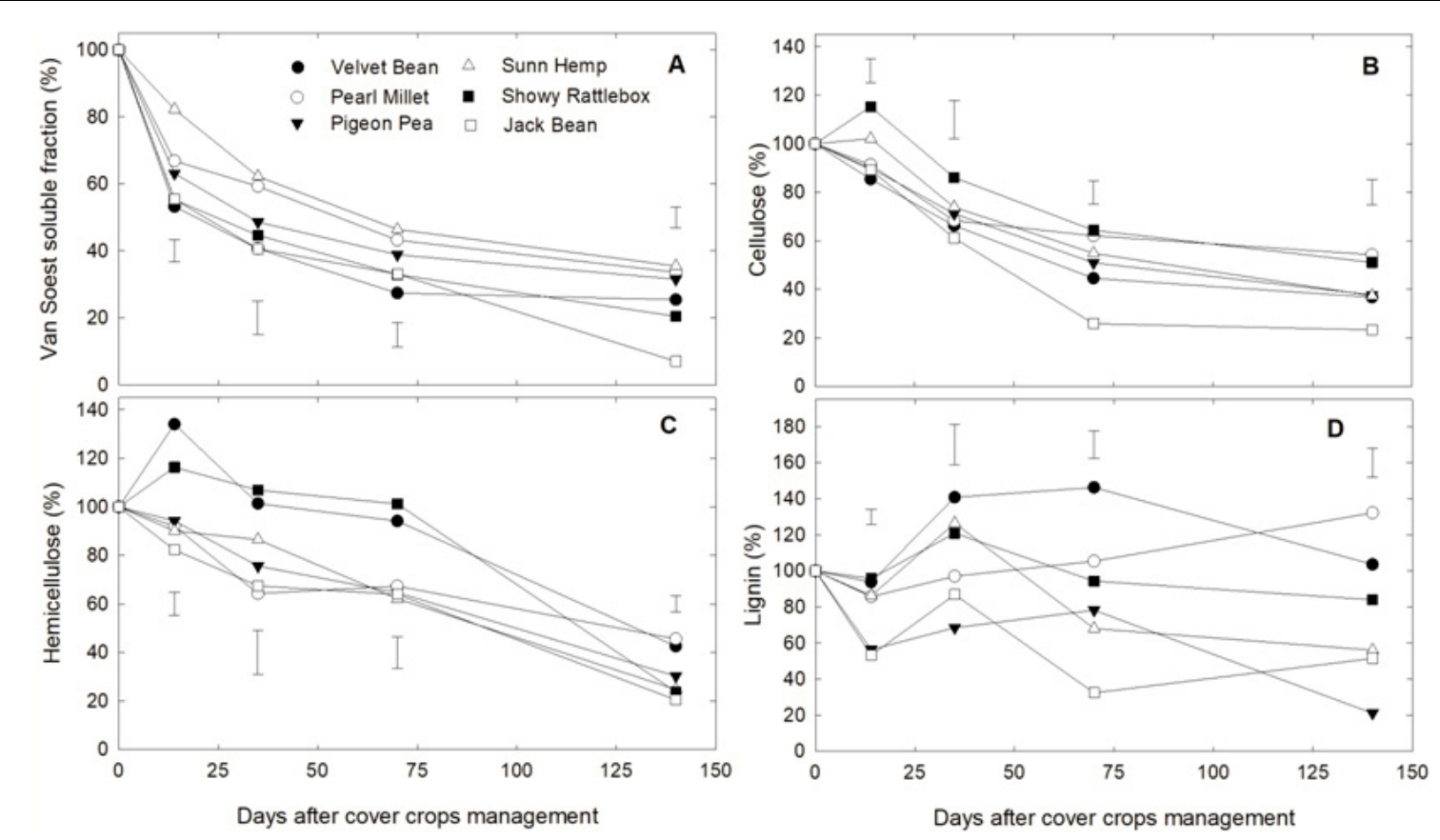

Figure 1 - Degradation of plant tissue components along of 140 days of evaluation. Vertical bars indicate minimum significant difference between the treatments (Tukey's test. $\mathrm{P}<0.05$ ).

on the initial period of decomposition (14 and 35 days), fact observed on velvet bean and crotalaria residues, can be the result of an artifact caused by the measurement of hemicellulose derived from the cell wall components and also from microbial-produced substances (HENRIKSEN \& BRELAND, 1999).

The degradation of lignin did not follow the same pattern observed on the other crop residue components, and it differed throughout the evaluation period (Figure 1D). At the end of the experiment, crop residues from pigeon pea, jack bean, sun hemp and crotalaria showed lignin degradation, whereas velvet bean and pearl millet showed an apparent increment on the levels of this component. Similar results were reported in other studies (BERTRAND et al., 2006; BERTRAND et al., 2009; SOUZA JR et al., 2017) and can be attributed to two factors that can lead to overestimation of the crop residue lignin content: 1)

Table 1 - Chemical composition of summer cover crops.

\begin{tabular}{|c|c|c|c|c|c|c|c|}
\hline Species & $\mathrm{C}$ & $\mathrm{N}$ & $\mathrm{C} / \mathrm{N}$ & SF & HEM & CEL & LIG \\
\hline & \multicolumn{7}{|c|}{ 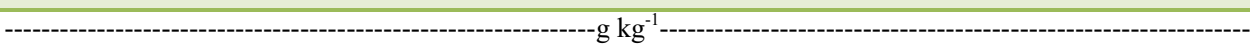 } \\
\hline Velvet bean & $437.3 \mathrm{ab}$ & $20.2 \mathrm{c}$ & $21.6 \mathrm{c}$ & $436.4 \mathrm{~b}$ & $77.9 \mathrm{c}$ & $364.2 \mathrm{~b}$ & $82.0 \mathrm{ab}$ \\
\hline Pearl millet & $430.2 \mathrm{bc}$ & $9.4 \mathrm{e}$ & $45.7 \mathrm{a}$ & $277.9 \mathrm{~d}$ & $259.8 \mathrm{a}$ & $366.3 \mathrm{~b}$ & $43.8 \mathrm{~d}$ \\
\hline Pigeon pea & $450.8 \mathrm{a}$ & $24.2 \mathrm{~b}$ & $18.7 \mathrm{c}$ & $375.0 \mathrm{c}$ & $142.2 \mathrm{~b}$ & $348.4 \mathrm{bc}$ & $92.3 \mathrm{ab}$ \\
\hline Sunn hemp & $436.7 \mathrm{ab}$ & $16.1 \mathrm{~d}$ & $27.1 \mathrm{~b}$ & $271.6 \mathrm{~d}$ & $146.3 \mathrm{~b}$ & $417.8 \mathrm{a}$ & $92.7 \mathrm{a}$ \\
\hline Crotalaria & $424.6 \mathrm{bc}$ & $22.1 \mathrm{bc}$ & $19.2 \mathrm{c}$ & $469.2 \mathrm{~b}$ & $86.5 \mathrm{c}$ & $316.5 \mathrm{c}$ & $84.8 \mathrm{ab}$ \\
\hline Jack bean & $418.4 \mathrm{c}$ & $36.2 \mathrm{a}$ & $11.6 \mathrm{~d}$ & $565.2 \mathrm{a}$ & $99.1 \mathrm{c}$ & $222.8 \mathrm{~d}$ & $60.8 \mathrm{bc}$ \\
\hline
\end{tabular}

C - carbon; N - nitrogen; SF - Van Soest soluble fraction; HEM - hemicellulose; CEL - cellulose; LIG - lignin. Values followed by equal letters do not differ by Tukey's test at $5 \%$ probability.

Ciência Rural, v.52, n.4, 2022. 
certain components can have reduced solubility due to the decomposition process; 2) physical separation (release) of least lignified components from crop residues.

Results of this study conducted on the field show that the soluble fraction of crop residues is rapidly degraded and/or leached after the cover crops termination, even if crop residues are left on the soil surface. Cellulose and hemicellulose have intermediate decomposition rate, being more important on the middle stages of decomposition, while lignin has higher recalcitrance and controls the crop residue degradation rates on more advanced decomposition stages. The degradation of the main crop residue components (soluble fraction, cellulose, hemicellulose and lignin) is determined by chemical and structural composition of each fraction.

\section{ACKNOWLEDGMENTS}

This research was supported by the Brazilian government through the Conselho Nacional de Desenvolvimento Científico e Tecnológico $(\mathrm{CNPq})$ and was financed in part by the Coordenação de Aperfeiçoamento de Pessoal de Nível Superior (CAPES), Brasil - Finance code 001.

\section{DECLARATION OF CONFLICT OF INTERESTS}

We have no conflict of interest to declare.

\section{AUTHORS' CONTRIBUTIONS}

The authors contributed equally to the manuscript.

\section{REFERENCES}

BERG, B.; MCCLAUGHERTY, C. Plant litter: decomposition, humus formation, carbon sequestration, 2nd ed. Springer, New York, 2020, 338p. Available from: <https:/www.springer.com/gp/ book/9783662499627> . Accessed: Jul. 29, 2021. doi: 10.1007/9783-030-59631-6.

BERTRAND, I. et al. Can the biochemical features and histology of wheat residues explain their decomposition in soil? Plant and Soil, v.281, p.291-307, 2006. Available from: <https://doi. org/10.1007/s11104-005-4628-7>. Accessed: Jul. 29, 2021. doi: $10.1007 / \mathrm{s} 11104-005-4628-7$.

BERTRAND, I. et al. Soil decomposition of wheat internodes of different maturity stages: Relative impact of the soluble and structural fractions. Bioresource Technology, v.100, p.155-163, 2009. Available from: <https://doi.org/10.1016/j. biortech.2008.06.019>. Accessed: Jul. 29, 2021. doi: 10.1016/j. biortech.2008.06.019.

COTRUFO, F. et al. Formation of soil organic matter via biochemical and physical pathways of litter mass loss. Nature Geoscience, v.8, p.776-781, 2015. Available from: <https://doi. org/10.1038/ngeo2520>. Accessed: Jul. 29, 2021. doi: 10.1038/ ngeo 2520 .

HENRIKSEN, T. M.; BRELAND, T. A. Evaluation of criteria for describing crop residue degradability in a model of carbon and nitrogen turnover in soil. Soil Biology \& Biochemistry, v.31, p.1135-1149, 1999. Available from: <https://doi.org/10.1016/ S0038-0717(99)00031-0>. Accessed: Jul. 29, 2021. doi: 10.1016/ S0038-0717(99)00031-0.

PEEL, M. C. Updated world map of the Köppen-Geiger climate classification. Hydrology and Earth System Sciences, v.11, n.5, p.16331644, 2007. Available from: <https://doi.org/10.5194/hess-11-16332007>. Accessed: Jul. 29, 2021. doi: 10.5194/hess-11-1633-2007.

PEREZ, J. et al. Biodegradation and biological treatments of cellulose, hemicellulose, and lignin: an overview. International Microbiology, v.5, p.53-63, 2002. Available from: <https://doi. org/10.1007/s10123-002-0062-3>. Accessed: Jul. 29, 2021. doi: $10.1007 / \mathrm{s} 10123-002-0062-3$.

REDIN, M. et al. How the chemical composition and heterogeneity of crop residue mixtures decomposing at the soil surface affects $\mathrm{C}$ and $\mathrm{N}$ mineralization. Soil Biology \& Biochemistry, 78, 65-75, 2014. Available from: <http://dx.doi.org/10.1016/j. soilbio.2014.07.014>. Accessed: Jul. 29, 2021. doi: 10.1016/j. soilbio.2014.07.014.

SANTOS, H. G. et al. Sistema brasileiro de classificação de solos. 2.ed. Rio de Janeiro: Embrapa Solos, 2006. 306p. Available from: $\quad<$ https://www.embrapa.br/en/busca-de-publicacoes/-/ publicacao/1107206/sistema-brasileiro-de-classificacao-desolos>. Accessed: Jul. 29, 2021.

SOIL SURVEY STAFF, 2014. Keys to Soil Taxonomy. USDANatural Resources Conservation Service, Washington, DC. Available from: <https://www.nrcs.usda.gov/wps/portal/nrcs/ detail/soils/survey/class/taxonomy/?cid=nrcs142p2_053580>. Accessed: Jul. 29, 2021.

SOUZA, JR. et al. Sugar cane straw left in the field during harvest: decomposition dynamics and composition changes. Soil Research, v.55(8), p.758-768. Available from: <https://doi.org/10.1071/ SR16310>. Accessed: Jul. 29, 2021. doi: 10.1071/SR16310.

VAN SOEST, P. J. Use of detergents in the analisys of fibrous feeds. I - preparation of fiber residues of low nitrogen content. Assoc. Off. Agric. Chem. J., v.46, p.825-829, 1963. Available from: <https://doi.org/10.1093/jaoac/73.4.487>. Accessed: Jul. 29, 2021. doi: 10.1093/jaoac/73.4.487.

VANLAUWE, B. et al. Residues fractionation and decomposition: The significance of active fraction. Plant and Soil, v.158, p.263274, 1994. Available from: $<$ https://doi.org/10.1007/BF00009500>. Accessed: Jul. 29, 2021. doi: 10.1007/BF00009500. 